University of Nebraska - Lincoln

DigitalCommons@University of Nebraska - Lincoln

Papers in the Earth and Atmospheric Sciences

Earth and Atmospheric Sciences, Department

$7-2011$

\title{
Environmental history of a closed-basin lake in the US Great \\ Plains: Diatom response to variations in groundwater flow regimes over the last $8500 \mathrm{cal}$. yr BP
}

\author{
William 0. Hobbs \\ University of Nebraska-Lincoln,whobbs@smm.org \\ Sherilyn C. Fritz \\ University of Nebraska-Lincoln, sfritz2@unl.edu \\ Jeffery R. Stone \\ University of Nebraska-Lincoln, jeffery.stone@indstate.edu \\ Joseph J. Donovan \\ West Virginia University, jdonovan@wvu.edu \\ Eric C. Grimm \\ Illinois State Museum, eric.c.grimm@outlook.com \\ See next page for additional authors \\ Follow this and additional works at: https://digitalcommons.unl.edu/geosciencefacpub \\ Part of the Geochemistry Commons, Hydrology Commons, and the Sedimentology Commons
}

Hobbs, William O.; Fritz, Sherilyn C.; Stone, Jeffery R.; Donovan, Joseph J.; Grimm, Eric C.; and Almendinger, James E., "Environmental history of a closed-basin lake in the US Great Plains: Diatom response to variations in groundwater flow regimes over the last 8500 cal. yr BP" (2011). Papers in the Earth and Atmospheric Sciences. 299.

https://digitalcommons.unl.edu/geosciencefacpub/299

This Article is brought to you for free and open access by the Earth and Atmospheric Sciences, Department of at DigitalCommons@University of Nebraska - Lincoln. It has been accepted for inclusion in Papers in the Earth and Atmospheric Sciences by an authorized administrator of DigitalCommons@University of Nebraska - Lincoln. 


\section{Authors}

William O. Hobbs, Sherilyn C. Fritz, Jeffery R. Stone, Joseph J. Donovan, Eric C. Grimm, and James E. Almendinger 


\title{
Environmental history of a closed-basin lake in the US Great Plains: Diatom response to variations in groundwater flow regimes over the last $8500 \mathrm{cal}$. yr BP
}

\author{
William O. Hobbs,' Sherilyn C. Fritz,' Jeffery R. Stone, ' \\ Joseph J. Donovan, ${ }^{2}$ Eric C. Grimm, ${ }^{3}$ and James E.Almendinger ${ }^{4}$ \\ I. University of Nebraska-Lincoln \\ 2. West Virginia University \\ 3. Illinois State Museum \\ 4. Science Museum of Minnesota \\ Corresponding author - William O. Hobbs, St Croix Watershed Research Station, \\ Science Museum of Minnesota, Marine on St Croix, MN 55047, USA; email whobbs@smm.org
}

\begin{abstract}
Sediment records from closed-basin lakes in the Northern Great Plains (NGP) of North America have contributed significantly to our understanding of regional paleoclimatology. A high-resolution (near decadal) fossil diatom record from Kettle Lake, ND, USA that spans the last 8500 cal. yr BP is interpreted in concert with percent abundance of aragonite in the sediment as an independent proxy of groundwater flow to the lake (and thus lake water level). Kettle Lake has been relatively fresh for the majority of the Holocene, likely because of the coarse substrata and a strong connection to the underlying aquifer. Interpretation of diatom assemblages in four groups indicative of low to high groundwater flow, based on the percent of aragonite in sediments, allow interpretations of arid periods (and probable meromictic lake conditions) that could not be detected based on diatom-based salinity reconstructions alone. At the centennial-millennial scale, the diatom record suggests humid/wet periods from $835 \mathrm{I}$ to 8088,4364 to I406 and 872 to $620 \mathrm{cal}$. yr BP, with more arid periods intervening. During the last $\sim 4500$ years, decadal-centennial scale periods of drought have taken place, despite the generally wetter climate. These droughts appear to have had similar impacts on the Kettle Lake hydrology as the "Dust Bowl" era droughts, but were longer in duration.
\end{abstract}

Keywords: closed-basin lake, diatom, groundwater flow, Northern Great Plains, paleoclimate, salinity

\section{Introduction}

Sediment records from closed-basin lakes in the climatically sensitive Northern Great Plains (NGP) of North America have contributed significantly to our understanding of regional paleoclimatology (Cumming et al., 2002; Fritz, 2008; Grimm, 2001; Laird et al., 2007; Teller and Last, 1990). Millennial-scale inferences of NGP paleoclimate over the Holocene have provided a cohesive picture of regional climate change, summarized mainly in paleoecological studies of pollen (Grimm, 2001), stable isotopes ( $\mathrm{Yu}$ et al., 2002), and diatoms (Fritz et al., 2000; Laird et al., 2007). A comprehensive picture of climatic variation at higher frequencies (centennial to decadal) has been hindered by the limited number of lakes with a complete sedimentary archive of the Holocene, as many lakes dried up in the arid mid Holocene, by adequate preservation of paleoenvironmental proxies, and by the variability in lake response to climate because of differences in local hydrology (Fritz, 2008).

In the NGP, diatom paleoecology and the use of numerical techniques to reconstruct lake-water salinity have provided high-resolution records of precipitation-evaporation (P-E) for periods of the Holocene (Fritz, 1990; Fritz et al., 2000; Laird et al., 1998). Sediment records also preserve geochemical evidence of groundwater flow through closed-basin lakes, in the form of authigenic precipitation of carbonate minerals, such as aragonite. In some groundwater-dominated lakes where lake water is enriched in carbonate relative to $\mathrm{Ca}$, and where groundwater inflow supplies dissolved $\mathrm{Ca}$, the authigenic carbonate precipitation to the lake bottom is a product of the rate of groundwater and Ca inflow (Grimm et al., 2011; Shapley et al., 2005).

Given the strong influence of both climate (P-E) and local hydrology on lakes in the NGP, robust reconstructions of Holocene environmental variations would incorporate proxies of both drivers. In this study we present a continuous high-resolution (near decadal) sediment record over the last $8500 \mathrm{yr}$ (cal. BP) from a closed-basin groundwater flow-through lake, Kettle Lake, in northwestern North Dakota, USA. We use the relationship of groundwater inflow and authigenic aragonite precipitation already established for the lake (Grimm et al., 2011) to interpret the stratigraphic diatom record using a new 
Figure I. Site location map of the North American continent $(\mathbf{A})$ and the Northern Great Plains (shaded area), including study site and additional sites discussed in the text (B). Bathymetry map of Kettle Lake, ND showing the uniform bowl-shape of the lake basin; contour interval is $2 \mathrm{~m}$ and shoreline elevation is $605 \mathrm{~m}$ a.s.I. (C).
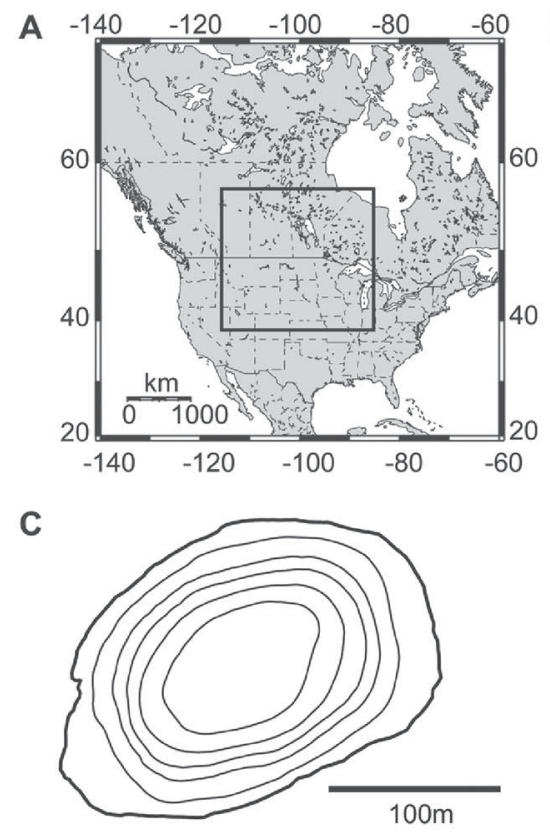

statistical approach. We show that reliance on a single proxy (diatom-inferred salinity) can lead to erroneous interpretations for some periods of record. In the NGP, this is the most highly resolved diatom record of Holocene paleoenvironmental change to date.

\section{Site description}

Kettle Lake $\left(48.607000^{\circ} \mathrm{N}, 103.624100^{\circ} \mathrm{W}, 605 \mathrm{~m}\right.$ a.s.l.) is located in northwest North Dakota, USA within the NGP (Figure 1). The lake is situated within the Little Muddy aquifer, which drains to the south to the Missouri River. Kettle Lake is a small (2.2 ha) bowl-shaped closed-basin (i.e. no surfacewater inflow or outflow) glacial kettle with a maximum depth of $10.2 \mathrm{~m}$ (Figure 1C). The region is underlain by coarse glacial outwash deposits from the Late Wisconsin glaciation. The relatively high permeability of the surrounding substratum gives the lake a strong connection with groundwater, and Kettle Lake is a flow-through groundwater-dominated lake. Indeed, the chemistry of the lake is not significantly different from the relatively fresh groundwater $(1.2 \mathrm{~g} / \mathrm{l})$ of the Little Muddy Aquifer (Donovan and Grimm, 2007). Because of this strong connection with groundwater, the salinity of Kettle Lake $(0.8 \mathrm{~g} / \mathrm{l})$ is somewhat anomalous in a region where lakewater chemistries are strongly driven by evaporative losses (Last, 1993). The current $\mathrm{pH}$ of the lake is 8.9 with a summer alkalinity of $490 \mathrm{mg} \mathrm{CaCO} / 1$ and conductivity of $1.7 \mathrm{mS} / \mathrm{cm}$. The climate of this region is semi-arid, with an annual deficit in precipitation-evaporation (Grimm, 2001) and lake water is depleted in $\mathrm{Ca}(30.4 \mathrm{mg} / \mathrm{l})$ relative to $\mathrm{HCO}_{3-}(549 \mathrm{mg} / \mathrm{l})$ (Donovan and Grimm, 2007). The mean annual range in air temperature is $-20^{\circ} \mathrm{C}$ to $28^{\circ} \mathrm{C}$. The lake is surrounded by mixedgrass prairie and is currently a managed recreation site by the North Dakota Game and Fish Department. The nearshore littoral zone is dominated by emergent bullrushes of the genus Schoenoplectus, while submerged Chara sp. dominate the deeper littoral zone of the lake.

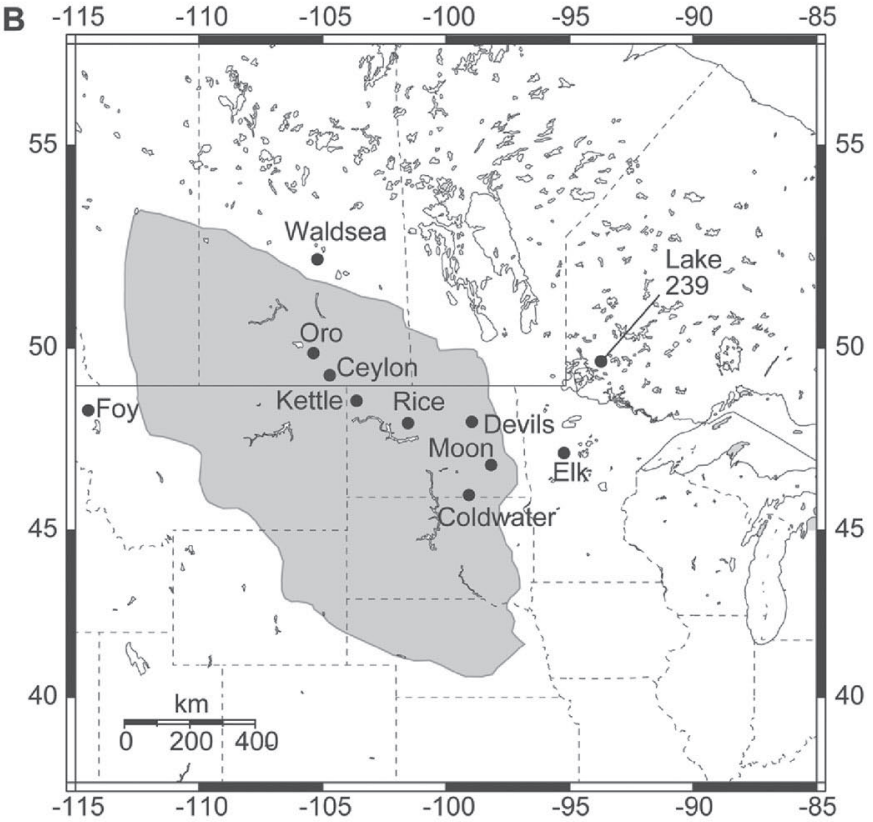

\section{Methods}

\section{Core collection}

Two overlapping cores spaced $\sim 1 \mathrm{~m}$ apart were obtained from the deepest point in the lake in July 1996 with a Wright square-rod piston corer (Wright, 1967). The two cores were aligned stratigraphically and a composite continuous sedimentary sequence $21.87 \mathrm{~m}$ in length was developed (Donovan and Grimm, 2007; Grimm et al., 2011). While laminations are present throughout the core, they are not consistently annual and cannot be used for varve chronology. However, their presence is representative of anoxic bottom waters in Kettle Lake, at least for part of the year, and an alternating seasonal sedimentation of dark organic and detrital clastic layers with light aragonite layers (Donovan and Grimm, 2007).

\section{Radiocarbon dating}

The calibrated AMS radiocarbon age-model for Kettle Lake is the most detailed and comprehensive in the NGP region (Grimm, 2011). The section of the core presented in this study comprises 35 independent dates (Figure 2). Radiocarbon dates were obtained from terrestrial macrofossils, namely seeds and charcoal. Calibrated ages were obtained using Bayesian methods with BCal (Buck et al., 1999) and the INTCAL09 calibration curve (Grimm, 2011; Reimer et al., 2009). The age model uses linear interpolation between the medians of the highest posterior density regions of the calibrated ages (Grimm, 2011).

\section{$\%$ Aragonite}

Percent aragonite by mass was obtained for each sediment interval through x-ray diffraction (XRD) using a PW-1800 diffractometer (Panalytical, formerly Philips, Eindhoven, The Netherlands) with $\mathrm{Cu}-\mathrm{K}$ radiation. XRD samples were airdried, crushed, filtered through a $100 \mu \mathrm{m}$ mesh, and mounted 
Figure 2. AMS radiocarbon age-model for the section of the core presented in this paper. Dates shown are the $95 \%$ posterior density regions from BCal (simple line). There is a $\sim 260 \mathrm{yr}$ gap in the age model due to a slump. Material was dated and modeled above, within, and below the slump and is described in detail by Grimm (20II).

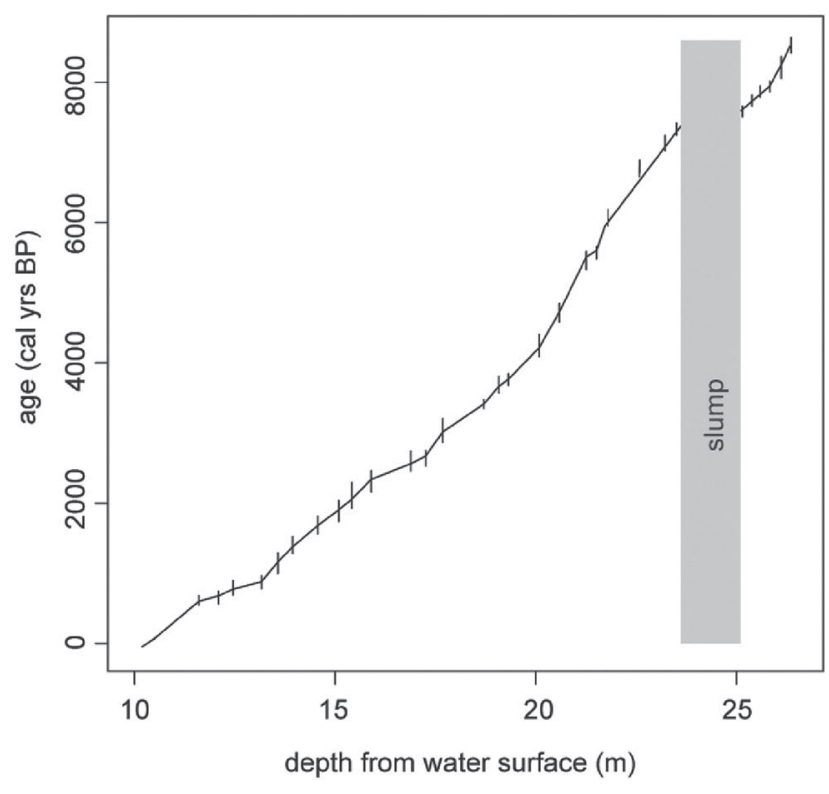

Bray-Curtis dissimilarity distances (Grimm, 1987). The zones were based on a uniform total sum-of-squares height and statistical significance was tested against a random broken-stick model (Bennett, 1996). A diatom-inferred salinity weightedaveraging transfer function (herein referred to as DI-salinity) was applied to the Kettle Lake core using a 77-lake training set spanning the salinity gradient of the Northern Great Plains (Fritz et al., 1993; Fritz, unpublished data, 2010). Salinity data were log transformed to reduce the right skewness and variability; consequently reconstructed salinity values as presented and discussed in this paper appear as $\log \mathrm{g} / \mathrm{l}$. The salinity values from the lakes used in the training set ranged from -1.17 to $1.62 \mathrm{log} \mathrm{g} / 1$ (0.06 to $41.69 \mathrm{~g} / \mathrm{l})$, with a mean of $0.36 \mathrm{log} g / 1$ (2.29 g/l) and median of $0.42 \mathrm{log} \mathrm{g} / 1(2.63 \mathrm{~g} / \mathrm{l})$. The species optima obtained from the training set are then used to estimate salinity concentrations throughout the core by a weighted-averaging model (Line et al., 1994). Species were not transformed or downweighted prior to running the model, and post-hoc testing of model performance by meanbootstrap methods over 999 cycles was used to give a root mean-squared error of prediction for the model (Line et al., 1994). All weighted-averaging calculations were made using the program C2 (Juggins, 2003).

The rate-of-change of the diatom assemblage can be interpreted as a measure of the stability of the diatom community through time. We determined the rate-of-change by linearly interpolating diatom percent abundance data to exactly 10-year intervals and calculating the chord distance between adjacent samples, a measure of dissimilarity (Jacobson and Grimm, 1986; Lotter et al., 1992). The chord distance is then divided by the amount of time (10 years) between samples, giving a rate-of-change. Interpolations were carried out using AnalySeries 2.0 (Paillard et al., 1996), while chord distance was calculated using the Analogue package in $\mathrm{R}$ ( $\mathrm{R}$ Core Development Team, 2010). A detrended correspondence analysis (DCA) was used to explore associations among diatom species and their respective salinity preferences. All diatom species were included in the analysis, with downweighting of rare species. Aragonite values for each sediment interval were

A stratigraphically constrained cluster analysis was used to determine zones within the diatom stratigraphy based on 
passively contoured on the DCA using thinplate splines in a general additive model, in order to visualize assemblages of dominant $(>10 \%$ in any one sample) diatom species over the gradient of groundwater-flow in Kettle Lake. Four groups of diatoms were identified as being associated with high, moderate-high, moderate-low, and low groundwater flow conditions based on common ranges of aragonite values. The DCA and contouring of the aragonite data was completed using $\mathrm{R}$.

\section{Results}

\section{Diatom communities and inferred salinity}

A total of 263 diatom species were identified over 667 sediment intervals. The preservation of diatom frustules was reliable in those samples counted, however, a large section of dissolution is evident from 7940 to 5960 cal. yr BP, with a shorter section from 5920 to 5840 cal. yr BP (Figure 3). Salinity tolerances for the dominant species ( $>30 \%$ relative abundance at any point in time) throughout the core are low, suggesting mainly freshwater or subsaline conditions throughout the last 8500 years (Figure 3$)$. In the section of core where diatom concentrations were analyzed ( 3500-6000 cal. yr BP), the absolute numbers of benthic diatoms varied less than planktic species. During periods of high overall diatom concentrations, planktic species were dominant. The most prevalent diatoms throughout the core were Stephanodiscus spp., which are planktic and generally have low Si:P requirements (Kilham et al., 1996). Stephanodiscus parous and Stephanodiscus minutulus are small $(<5 \mu \mathrm{m})$, share similar ecological preferences, and are difficult to distinguish using light microscopy; we therefore combined these two species as a "complex." Additional planktic freshwater species with moderate to high Si:P requirements include Asterionella formosa, Fragilaria crotonensis, and Fragilaria capucina var. mesolepta. A number of freshwater planktic Synedra spp. were present in the sediments: S. acus, S. acus var. angustissima, S. tenera, and S. nana. Gomphonema clavatum, an epiphyte, was the only abundant benthic freshwater diatom. Other gomphonemoid diatoms present were Gomphoneis olivaceum and Gomphonema aquaemineralis, both epiphytic and subsaline. Achnanthidium minutissimum, a common 'weedy' epipelic diatom was present throughout the core, in addition to A. microcephalum. Planktic diatoms with subsaline affinities include Cyclotella meneghiniana, Nitzschia palea, and $N$. paleacea. The majority of subsaline diatoms in Kettle Lake are benthic and epiphytic or epipelic. Chaetoceros spp. were found throughout the core, predominately in an encysted stage, and we have combined C. elmorei and C. muelleri as the cysts for these two species could not be differentiated. Chaetoceros is planktic with typically hyposaline tolerances. Stratigraphically constrained cluster analysis of the full diatom assemblages shows three main zones over the last 8500 years (Figure 3): 8500 to 4364 cal. yr BP (Zone 1), 4364 to 620 cal. yr BP (Zone 2), and 620 to -41 cal. yr BP (Zone 3). Subzones are distinguished within these primary zones. The independently established diatom zone 1-2 boundary at 4364 cal. yr BP is remarkably similar to the major D-E boundary in pollen and mineral data placed at $4440 \mathrm{cal}$. yr BP from the same core. This boundary was based on independent CONISS cluster analyses of mineral and pollen data and is the mean of major partitions in the dendrograms for minerals at $4290 \mathrm{cal}$. yr BP and pollen at 4590 cal. yr BP (Grimm et al., 2011). Thus, all proxies show a major environmental regime shift at $\sim 4400$ cal. yr BP.

The DI-salinity reconstruction for Kettle Lake shows few instances when statistically significant changes in salinity (beyond the model error) have occurred over the course of the last 8500 years (Figure 4). The root-mean-square standard error of prediction for the model is $0.53 \log \mathrm{g} / \mathrm{l}$. Nonetheless, at millennial-scale resolution three stages of differing mean salinity are present; the arid mid Holocene (mean $0.06 \mathrm{log} \mathrm{g} / \mathrm{l}$; 81004364 cal. yr BP in this record), the late-Holocene wet period (mean -0.50 log g/l; 4364-2300 cal. yr BP), and an intermediate late-Holocene period (mean $-0.12 \log \mathrm{g} / \mathrm{l} ; 2300 \mathrm{cal}$. yr BP to present). Relative to the modern salinity of Kettle Lake $(-0.10$ $\log g / 1)$, the salinity in the first part of the arid mid Holocene is consistently higher $(\sim 8000-5800$ cal. yr BP). This is followed by centennial periods of lower and higher salinity over the next 1200 years (5800 to $\sim 4600$ cal. yr BP), until the transition to the wetter late-Holocene period begins. Kettle Lake appears fresher today than it was for most of the late Holocene, from $\sim 2200$ cal. yr BP to present. During this period mean salinity was similar to modern, but multidecadal and centennial arid periods are prominent, producing greater variability in the DIsalinity record than previously. The current salinity of Kettle Lake and the value of the uppermost-reconstructed sample are similar, suggesting confidence in the reconstructed values. However, in some periods the reconstructed salinity is lower than at other lakes in the same region (e.g. the mid-Holocene period 5400-4800 cal. yr BP; Figure 4).

\section{\% Aragonite stratigraphy}

The detailed record of authigenic aragonite for the last 8500 years in Kettle Lake is a proxy for the groundwater flow into the lake (Grimm et al., 2011). The record appears to have a multicentennial cyclicity overlaid by millennial-scale shifts in deposition (Figure 4). During the arid mid Holocene (diatom zone $1 \mathrm{c}$ and $1 \mathrm{~d}$; 8100-4364 cal. yr BP) the range in \% aragonite is larger than the wet late Holocene (diatom zone $2 \mathrm{a}$ and 2b; 4364-1400 cal. yr BP), with concentrations averaging $~ 47 \%$ and $65 \%$, respectively. The period of lowest aragonite deposition is diatom zone $1 \mathrm{~d}(5400-4364$ cal. yr BP), which is punctuated by prolonged droughts (Figure 4; Grimm et al., 2011). A more thorough presentation and discussion of the paleoclimatic inferences over the entire Holocene from the aragonite data can be found in Grimm et al. (2011), here we use the aragonite concentrations to improve our understanding of diatom response to changes in groundwater flow.

\section{DCA and groundwater flow regimes}

We used DCA to determine whether the distribution of the core diatom species in ordination space shows distinct grouping by salinity preference (Figure 5). No apparent grouping of species by salinity preference is evident on the first two axes. The total gradient length of DCA axis 1 is 3.3 SD units, suggesting a unimodel diatom response, and the explanatory power of the first and second axes is $19 \%$ and $14 \%$, respectively. To aid in the interpretation of the core diatom distribution the aragonite concentration for each corresponding sediment sample was then passively introduced to the ordination space and contoured. This approach has the advantage of incorporating both axes of variation within ordination space, as the aragonite is contoured across both. The gradient of aragonite across the ordination space represents a gradient of high (high aragonite concentra- 


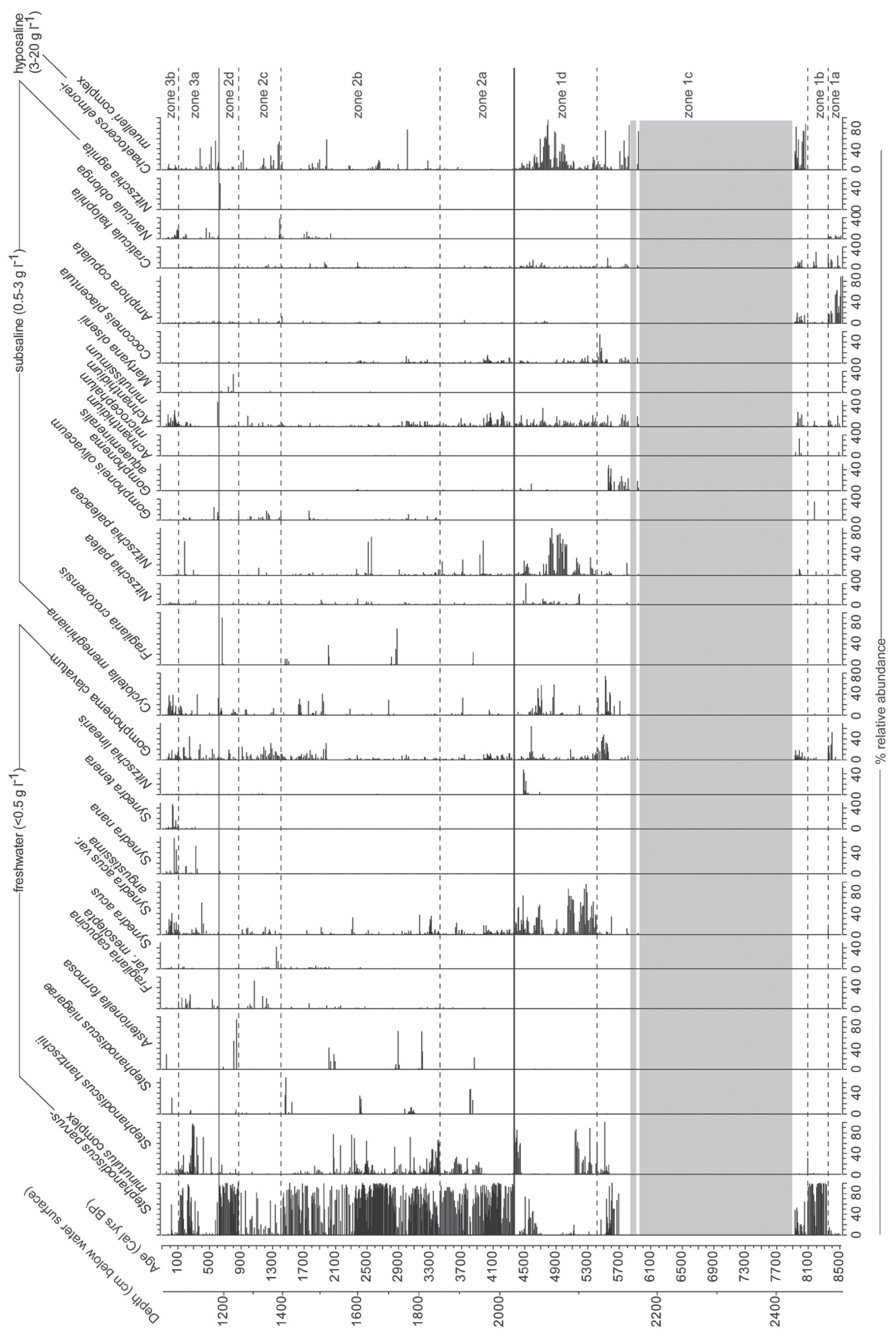




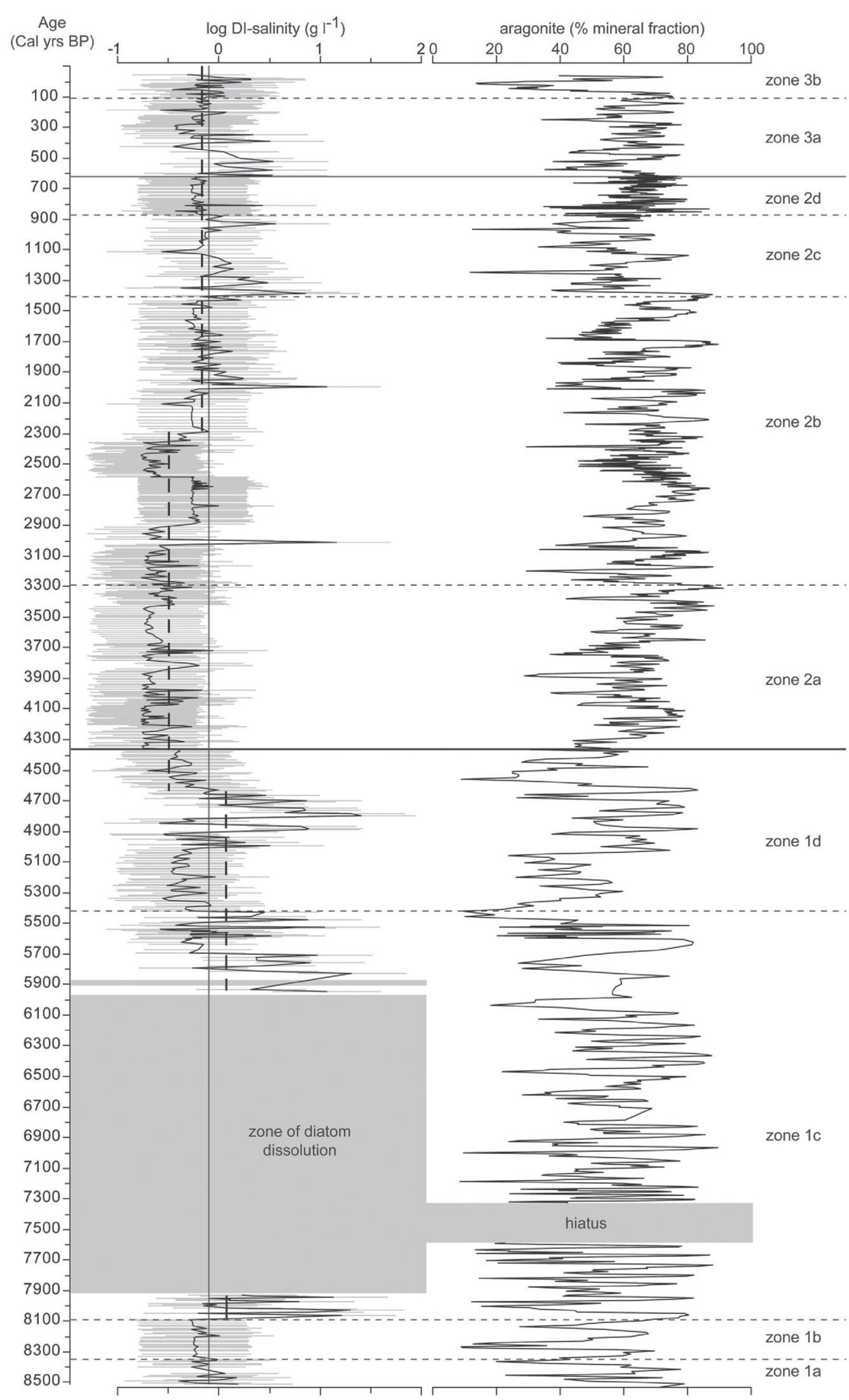

Figure 4. Diatom-inferred salinity reconstruction in $\log g / l$. The root-mean squared error of prediction for the model is present for each data point as a grey error bar. Solid line is the current salinity of Kettle Lake $(-0.09 \log \mathrm{g} / \mathrm{l})$, while millennial-scale mean salinity for the mid- and late-Holocene periods shown in dashed lines $(0.053,-0.503$, and $0.117 \mathrm{log} g / \mathrm{l})$. Aragonite concentrations as \% mineral fraction. Diatom zones are overlain as per Figure 3 . 
Figure 5. DCA of all diatom species classified according to salinity preference. Corresponding aragonite concentration (\% mineral fraction) for each sample is passively contoured in ordination space

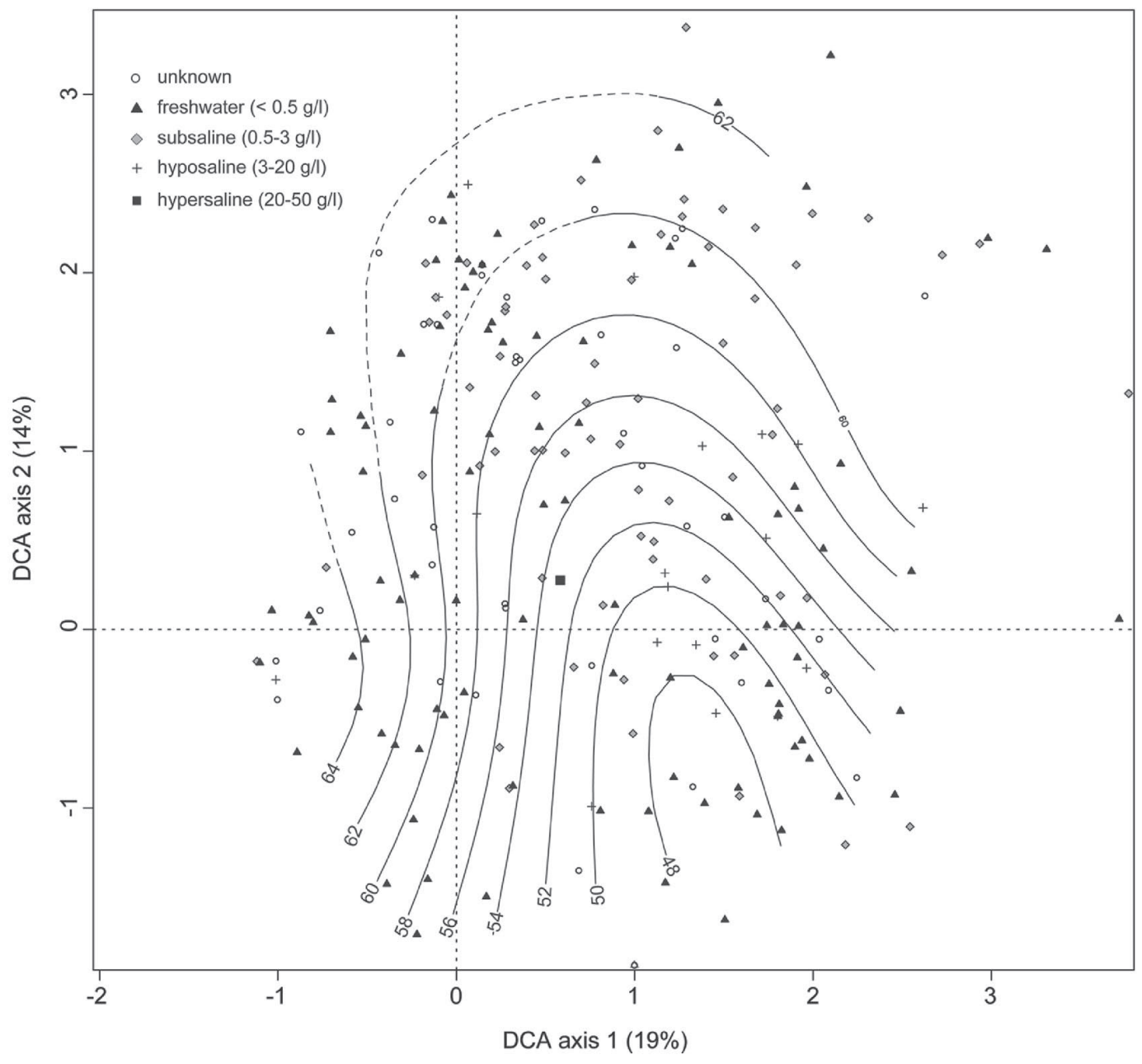

tion) and low (low aragonite concentration) groundwater flow and groundwater elevation (Figure 5).

\section{Diatom-inferred lake states}

The visualization of high and low groundwater flow enables us to semi-quantitatively define the diatom assemblages that are associated with flow regimes over the two main gradients (DCA axis 1 and 2) of diatom change. In so doing we can establish the dominant ( $>10 \%$ at any point in the record) diatoms present during high (group $1 ;>62 \%$ aragonite), moderate-high (group 2; 56-62\% aragonite), moderate-low (group $3 ; 50-56 \%$ aragonite), and low (group $4 ;<50 \%$ aragonite) groundwater flow. The modern ecological affinities of the diatom assemblages associated with each groundwater regime are used to elucidate physical and chemical attributes of the lake during the four broadly defined states (Figure 6), as discussed in detail in the subsequent sections.

\section{Discussion}

\section{DCA-defined diatom groups (Figure 6)}

Diatom group I: High groundwater flow, deep lake. This group of diatoms is dominated by freshwater euplanktic species (predominantly Stephanodiscus spp.) (Figure 6). The small domi- nant $(<5 \mu \mathrm{m})$ Stephanodiscus parous-minutulus complex typically blooms in the spring during lake overturn when Si:P is low, but can survive into stratification (Kilham et al., 1996; Stoermer and Håkansson, 1984). These diatoms imply that the lake state during high groundwater flow is likely dimictic and that most diatom growth is taking place after ice-out, when hypolimnetic phosphorus is being recycled from the sediments into the photic zone (Bradbury, 1988). Stephanodiscus niagarae and to a lesser extent Stephanodiscus medius are also present in this group. S. niagarae commonly blooms following the onset of stratification and into the late summer, typically occupying hypolimnetic waters (Bradbury, 1988; Kilham et al., 1996).

Asterionella formosa is euplanktic, forms stellate colonies, and has an intermediate to high Si:P requirement (Saros et al., 2005; Tilman et al., 1982). A. formosa can bloom in the late spring or the late summer during periods of low phosphorus regeneration and high silica. A. formosa is often found in association with Fragilaria crotonensis (as it is in the Kettle Lake sediments), which has similar resource requirements to $A$. formosa and has been observed at high abundances near the thermocline after spring mixing (Bradbury, 1988). F. crotonensis blooms in the late spring and early summer when stratification is establishing and phosphorus is becoming depleted.

Benthic diatoms in this group are low in relative abundance, reflecting the relatively low proportion of benthic habitat (Wolin and Stone, 2010) (Figure 6). The narrow littoral bench of 


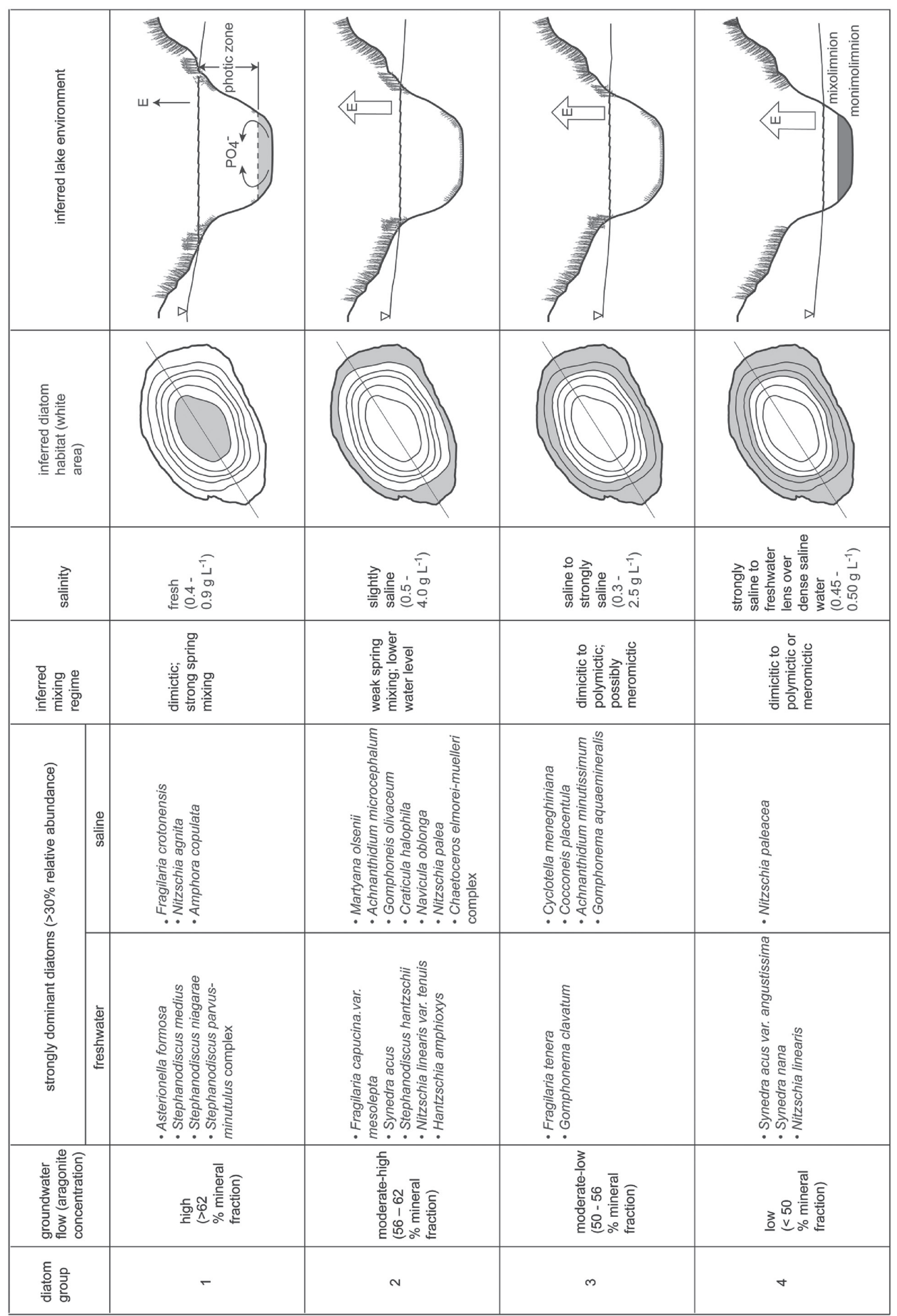

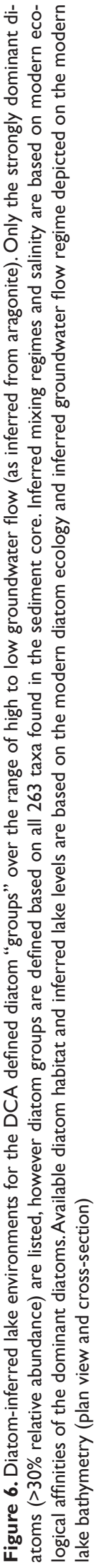


Kettle Lake is the sole area suitable for diatom growth, because it is unlikely that the photic zone is sufficient to reach the lake bottom at high water levels and high groundwater flow given modern Secchi depths of approximately $4.5 \mathrm{~m}$.

Diatom group 2: Moderate-high groundwater flow, lower lake-level. During somewhat lower groundwater flow, the diversity of benthic diatoms increases dramatically. A number of freshwater and subsaline epiphytic species of the genus Gomphonema, Cocconeis, Achnanthidium, Amphora and Cymbella are present, suggesting a greater abundance of submerged or emergent aquatic vegetation on the littoral bench of the lake. This would be expected as lake level and groundwater flow is slightly lower, and suitable habitat becomes available. A number of epipelic diatoms with subsaline affinities (e.g. Mastogloia smithii and Craticula halophila) also occur, in addition to a number of Nitzschia spp. that are generally found in waters of high ionic strength (Cumming et al., 1995). The increased dominance of epipelic diatoms is likely a result of the photic zone extending to the lake bottom and increasing the proportion of benthic habitat (Wolin and Stone, 2010) (Figure 6).

The inferred increase in salinity is supported by the presence of the planktic, hyposaline Chaetoceros muelleri-elmorei complex. The colonial euplanktic C. muelleri-elmorei complex can form heavily silicified resting cells (which is the predominate form found in the sediment records), thus it is meroplanktic and dominates during periods of strong mixing. The increase in inferred salinity would result from greater evaporative loss from the lake due to lower groundwater flow. Changes in salinity in response to the P-E balance of closedbasin lakes have proven a robust relationship in the NGP (Fritz, 1990; Laird et al., 1996; Last, 1993).

Diatom group 3: Moderate-low groundwater flow, low lake-level. During periods of a low groundwater gradient, the lake level drops, and an increase in evaporative loss would favor diatoms with saline affinities. Indeed, the planktic diatom Cyclotella meneghiniana, which has a subsaline affinity, is dominant in this group. C. meneghiniana is a common species in the lakes of the NGP throughout the Holocene (Fritz et al., 1993, 2000; Laird et al., 2007) and has been observed to bloom in the late summer in Kettle Lake (J. E. Saros, personal communication, 2010), presumably during periods of strong stratification, conditions that are common in this genus (Bradbury, 1988; Winder et al., 2009). C. meneghiniana is also an efficient user of Si and generally has a low Si:P requirement (Tilman and Kilham, 1976). Additional spring-early summer blooming planktic species present in this group (Synedra tenera and Stephanodiscus hantzschii) suggest that fresher conditions perhaps prevailed soon after winter ice-out, despite the lower groundwater flow and lake level. Synedra tenera, a freshwater planktic diatom, is associated with C. meneghiniana in the fossil assemblages and is competitive under similar lake thermal characteristics and low P (Interlandi et al., 1999). The presence of S. hantzschii in group 3 is somewhat unexpected as the other Stephanodiscus spp. with low Si:P are associated with group 1 and high groundwater flow, however previous studies show that $S$. hantzschii is favored in lakes with high alkalinity (Brugam, 1983).

The benthic community of this group is less diverse than group 2 but contains some epiphytic taxa commonly associated with saline conditions, namely Cocconeis placentula and Gomphonema aquaemineralis. The presence of epipelic Nitzschia perminuta and $N$. liebtruthii, which have salinity optima in the mesosaline (> $20 \mathrm{~g} / 1)$ and hyposaline (3-20 g/l) range, respectively, and which are the highest salinity ranges found throughout the sediment record, adds further evidence of saline conditions during periods of low groundwater flow. A number of epipelic Navicula sensu lato species (e.g. Luticola mutica and Navicella pusilla) with freshwater and subsaline affinities are also present in this group.

Diatom group 4: Low groundwater flow, meromictic lake. Few diatom species are associated with low groundwater flow conditions in Kettle Lake. Salinity is likely to be at its highest during periods of the lowest groundwater flow and lake level, however, the planktic freshwater diatoms Synedra acus var. angustissima, S. nana, and Nitzschia linearis are dominant at these times. These three species share similar life strategies and form stellate colonies which facilitate their euplanktic habit. S. acus var. angustissima has high Si:P requirements and implies weak or no mixing of the water column (Bradbury, 1988). Brugam (1983) showed that S. nana is typical in naturally meromictic lakes in Minnesota. Therefore these two species imply that at the lowest groundwater flow, the lake becomes meromictic. S. acus var. angustissima and $S$. nana bloom in the spring and need a freshwater mixolimnion, which snow and ice-melt would provide. This freshwater lens would remain chemically isolated from deep saline waters under meromictic conditions.

Nitzschia paleacea is also dominant in this low groundwater flow group and can inhabit periphytic and planktic environments, forming both rosette and stellate colonies, respectively. It is commonly found in alkaline, slightly brackish waters. It has been described as an obligatory nitrogen heterotroph and is tolerant of heavy organic pollution (Hürlimann and Schanz, 1993; Lange-Bertalot, 1978). It is unclear where in Kettle Lake this diatom would have been growing, but likely it occurred below the mixolimnion, where conditions would be more alkaline and ammonium supply from the sediments would be plentiful. Interestingly, $N$. paleacea and $S$. acus var. angustissima are present in alternating time periods in the sediment record (Figure 3), suggesting varied degrees of meromixis, with $N$. paleacea signifying a greater monimolimnetic habitat. The modern and historical association of Synedra acus var. angustissima and Nitzschia paleacea in meromictic systems is not without precedent and has been elegantly presented using varved sediments, sediment traps, and phytoplankton samples in a Turkish lake (Woodbridge and Roberts, 2010). No benthic diatoms are dominant in this group.

\section{Diatom-inferred lake water salinity}

The reconstructed diatom-inferred salinity for Kettle Lake varies over decadal, centennial, and millennial timescales for the last 8500 cal. yr BP (Figure 4). The DI-salinity suggests that Kettle Lake has been significantly fresher than today during multiple periods throughout its history, including during part of the arid mid-Holocene period. This is particularly surprising during the period 5400-5000 cal. yr BP, when groundwater flow appears to be at its lowest and group 4 diatoms dominate (Figure 7). While we have established that the weighted-averaging salinity model is statistically significant for Kettle Lake, the diatom species in "group 4" are not well represented within the training set. The two dominant diatoms for this group, Nitzschia 


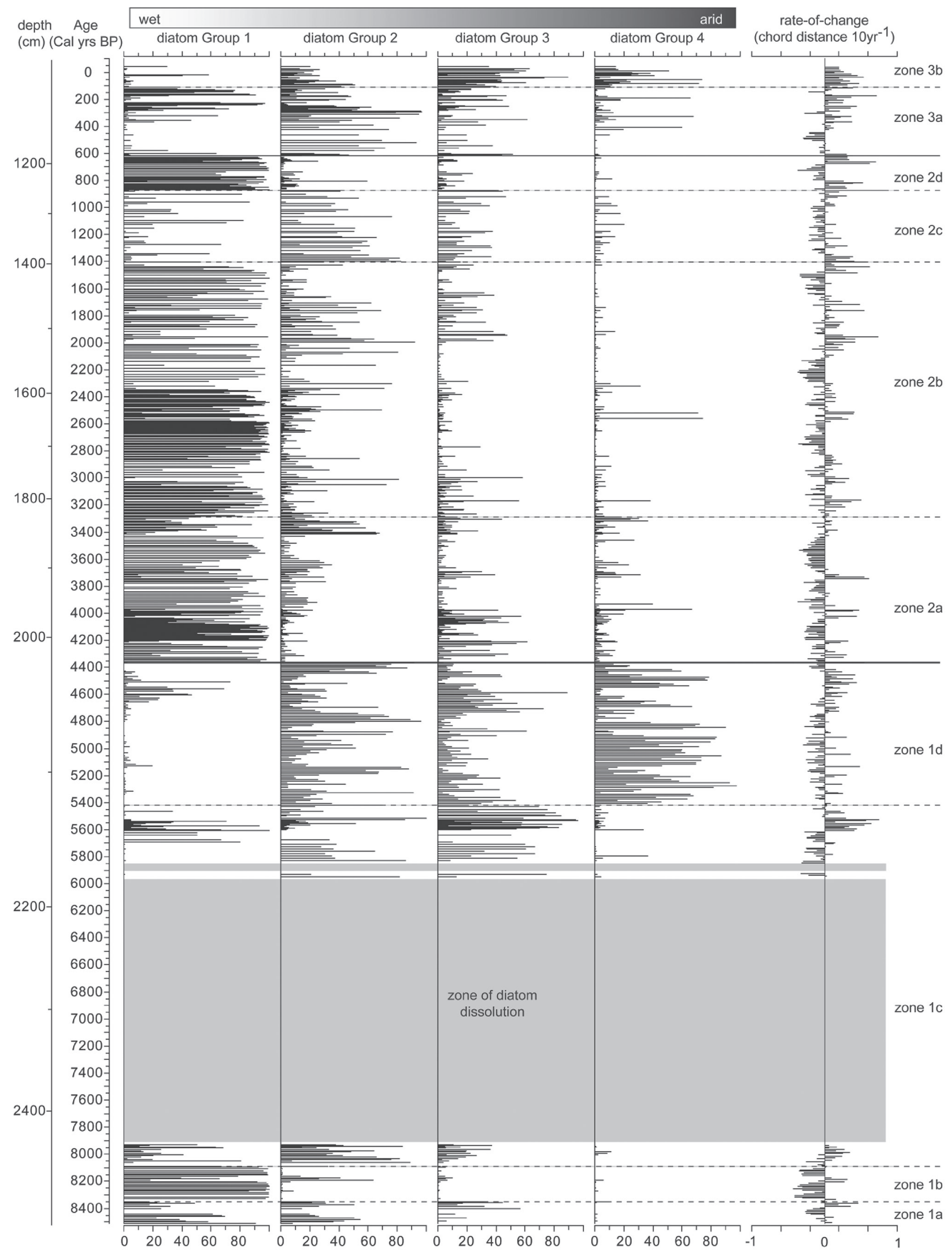

Figure 7. Diatom stratigraphy for Kettle Lake, ND grouped in accordance with defined assemblages of high (group I) to low (group 4) groundwater flow. Diatom assemblage rate-of-change represents the stability of the diatom communities through time, expressed as departure from the mean of chord distance per $10 \mathrm{yr}$. Stratigraphic zones are defined by original zones of all taxa as shown in Figure 3. 
paleacea and Synedra acus var. angustissima, are present in nine and eight of the 77 training set lakes, respectively. More importantly, the relative percent abundance of these diatoms does not exceed $2 \%$ within the training set, meaning that the salinity optima of these two species of diatoms is not well constrained. Therefore during periods of the salinity reconstruction when these two diatoms dominate the assemblage (up to $>80 \%$ relative abundance), the inferred lake environment is not represented by the training set. We infer that periods of the record that are dominated by group 4 diatoms and the lowest groundwater flow actually represent a much more arid period than suggested directly by the salinity reconstruction. The taxa found in group 4 suggest a meromictic water column and are likely growing in a fresh mixolimnion lens overlying a highly saline monimolimnion. Thus, the diatom-inference of fresh surface waters likely is correct, but in this case relatively fresh surface waters occur during arid climatic conditions.

Overall the DI-salinity of Kettle Lake has a small range in variability over the last 8500 years. Kettle Lake's modern salinity is comparatively very low for the NGP, because it is a groundwater flow-through lake in a very coarse substratum that is fed by fresh groundwater (Donovan and Grimm, 2007; Grimm et al., 2011). Our salinity reconstruction results suggest that Kettle Lake has maintained this strong connection to the groundwater system throughout the last 8500 years, thus buffering the lake's response to drought.

\section{Environmental history of the Kettle Lake region}

The stratigraphic summation and presentation of the defined "groups" of diatoms reduces the complexity of a species-rich community, while offering a temporally detailed view of diatom response to variations in groundwater over the last 8500 years (Figure 7). We now discuss the environmental history of Kettle Lake through the three main zones of the core in the context of regional environmental change.

Zone I (8500-4364 cal. yr BP). The base of the Kettle Lake diatom record $(8500 \mathrm{cal}$. yr BP), dates to the mid-Holocene arid period of the NGP (Dean et al., 1996). The base of zone 1 (zone 1a; 8500-8351 cal. yr BP) represents a period of moderate-low groundwater flow into a well-mixed deep saline lake (Figure 7). Subsequently, the diatoms indicate a shift to wetter climate at 8351 cal. yr BP (zone 1b, Figure 6; 8320-8088 cal. yr BP) or at least a fresher lake from greater groundwater flow (Figure $7)$. This shift, which appears abrupt in the diatom record, culminates a gradual and variable increase in aragonite following the major drought and aragonite minimum at $\sim 9250$ cal. yr BP (Grimm et al., 2011). So whereas the aragonite indicates a gradual increase in moisture, the diatoms may indicate a threshold response. A brief event occurring at $\sim 8200$ cal. yr BP where diatom Groups 2 and 3 become dominant suggests more saline conditions and an arid climate. This observation is similar to other studies in this region where a cool, windy, dry period is inferred in response to this climatic event (Alley et al., 1997; Dean, 1993). This event is not extraordinary during the early mid Holocene, but does correspond with one of the lowest aragonite minimums and by inference severe droughts of the Holocene (Grimm et al., 2011), and the synoptic climatology associated with the $8.2 \mathrm{ka}$ event in Greenland may have exacerbated a cyclical NGP drought owing primarily to other causes.

At approximately 8100 cal. yr BP Kettle Lake became dra- matically more saline, and the diatom assemblages subsequently were less stable (zone 1c, Figure 7). The timing of this transition corresponds with abrupt expansion of prairie to the east at Elk Lake, Minnesota (Dean et al., 1996). To the northwest of Kettle the transition to the mid-Holocene arid period began earlier (c. 9000 cal. yr BP), as lake level dropped in Ceylon Lake and the basin became closed (Last, 1990). At Kettle Lake diatoms were lost from the sediments because of dissolution beginning $\sim 7920 \mathrm{cal}$. yr BP. This phenomenon commonly occurs in highly saline environments (Ryves et al., 2009) and lasted in Kettle until $\sim 5950$ cal. yr BP. The period of diatom dissolution also corresponds with an intensely dry period, based on other proxies (Grimm et al., 2011).

From 5950 cal. yr BP until 4364 cal. yr BP, the diatom assemblages have a high rate-of-change, suggesting an unstable community, fluctuating among lake states on decadal to centennial timescales (Figure 7). A saline, well-mixed lake dominated by group 2 and 3 diatoms was prevalent above the diatom dissolution zone, similar to the lake state prior to the dissolution (Figure 7). At 5700 cal. yr BP Kettle became intermittently fresher for $\sim 200$ years, followed by a dramatic shift to high salinity and inferred arid conditions at 5419 cal. yr BP (zone 1d, Figure 6). This climatic inference from diatoms corresponds well with the inference from aragonite data, which indicate an extended pluvial period $\sim 5700-5600$ cal. yr BP, followed by an intense drought centered at $\sim 5400$ cal. yr BP (Figure 4; Grimm et al., 2011). At this time Kettle Lake enters a period where meromixis (group 4 diatoms) becomes a dominant lake state (Figure 7), alternating with saline conditions and moderate-low groundwater flow (group 3 diatoms) (Figure 7).

Evidence for meromictic conditions during this time period also comes from authigenic mineral deposits of struvite (hydrous Mg-ammonium-phosphate), in the same Kettle Lake core between 8700 and 4650 cal. yr BP (Donovan and Grimm, 2007). Struvite is a guano mineral, occurring in animal waste and requiring an anoxic sedimentary environment, such as is characteristic of a meromictic lake. Donovan and Grimm (2007) hypothesized that during the arid mid Holocene, the relatively deep Kettle Lake would be one of a small number of lakes in the NGP that still contained water, causing a dramatic increase in migratory waterfowl, guano deposition, and preservation of struvite. The presence of this mineral and the dominant diatom Nitzschia paleacea (an obligate $\mathrm{N}$ heterotroph, tolerant of heavy organic pollution) further supports the inference of a meromictic lake environment at this time. Meromixis could become established under continued warm and arid conditions which drive further lowering of groundwater flow and increased evaporative loss from the lake, which continued to increase salinity and produced strong chemical stratification. As a result of infilling, the lake basin would have been approximately $10 \mathrm{~m}$ deeper or double the present depth at this time, making meromictic conditions easier to establish (Figure 8). It appears that while group 4 diatoms suggest meromictic conditions, their abundance is not necessarily related to the strength or stability of meromictic conditions. This is demonstrated by the sustained high values of group 4 diatoms in the lower half of zone $1 \mathrm{~d}$ from $\sim 5400$ to 5000 cal. yr BP (Figure 7) which correspond with a sustained period of intermediate aragonite values with little variability, suggesting relatively dry, but not intensely dry, conditions, and thus a sustained drought of intermediate intensity. It is perhaps the persistence of low lake-levels and a relatively large monimolimnion that favors group 4 diatoms dur- 

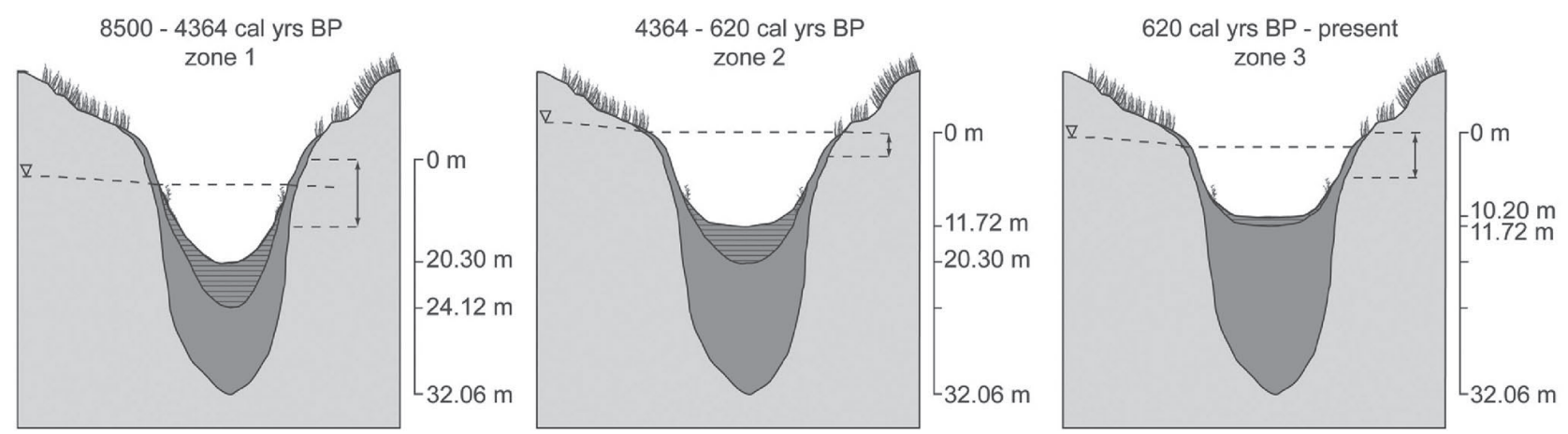

Figure 8. Schematic cross-sections of Kettle Lake, ND through time as defined by the main diatom zones. Historical lake depths and infilling are based on linear interpolations of basin morphology and the age-model. The estimated range in lake levels are shown as dashed lines, subjectively inferred from the diatom defined lake states, with the predominant groundwater level as the lake level. The vertical axis represents the depth from modern water surface in meters.

ing this time. In addition, throughout the entire mid Holocene the sediment is finely laminated (Grimm et al., 2011), and the period of struvite occurrences overlaps with a large zone of diatom dissolution (Donovan and Grimm, 2007), suggesting that meromictic conditions are not specific to periods when group 4 diatoms dominate.

A 200 year period of fresher conditions prevailed from 4750 to 4550 cal. yr BP, prior to the most significant shift (greatest sum-of-squares height in the diatom cluster analysis) at 4364 cal. yr BP, when the mid-Holocene arid period switched abruptly to a wetter late-Holocene period. This 200year period also corresponds with wet conditions implied by the aragonite data (Figure 4; Grimm et al., 2011). The age of this shift in diatoms falls between the major breaks in pollen and mineral data respectively at 4290 and 4590 cal. yr BP. Thus, all proxies (minerals, pollen, and diatoms) indicate a major climatic mode shift during this period.

Zone 2 (4364-620 cal. yr BP). Kettle Lake was generally fresh, dimictic, and influenced by high groundwater flow during zone 2 (Figures 7 and 8). The sedimentation rate also increased at $\sim 4500$ cal. yr BP, possibly as a result of increased aquatic production (Figure 2). This sharp transition to zone 2 is also the strongest shift in the pollen and mineral records for Kettle (Grimm et al., 2011). The dramatic shift to a wet late-Holocene period is well documented in a number of records from the NGP (Laird et al., 2007). Indeed, the timing of this transition in Ceylon and Waldsea Lakes to the north of Kettle Lake (Figure 1) occurred within $\sim 50$ years of the event at Kettle Lake. To the east of the NGP, Lake 239 in Ontario and Elk Lake, Minnesota recorded dramatic secular changes at 4435 cal. yr BP and $\sim 4200$ varve years before AD 1980, respectively (Bradbury and Dieterich-Rurup, 1993; Laird and Cumming, 2008). To the west of Kettle, Foy Lake in the Rocky Mountains of Montana also exhibits large diatom assemblage shifts at c. $4500 \mathrm{cal}$. yr BP (Stone and Fritz, 2006). Here, Stone and Fritz (2006) present evidence for a significant climate state change associated with an apparent reduction in strength of forcing by the Pacific Decadal Oscillation. Such a shift in the relative influence of Pacific versus Atlantic sea-surface temperature might be associated with an increase in moisture from low-level summer southerly air masses from the Gulf of Mexico, as hypothesized in other regional paleoclimatic studies (Dean et al., 1996).

Multidecadal to centennial length drought periods dominated by the saline diatoms in group 2 or 3 , are evident dur- ing the wetter period in Kettle Lake from 4364 to 1406 cal. yr BP (e.g. 3442 to 3268 cal. yr BP and 1950 to 1700 cal. yr BP (Figure 7)). However, there is no evidence of a mega-drought beginning at c. $4200 \mathrm{cal}$. yr BP and persisting for several hundred years, as has been observed in a number of North American paleoclimatic records (Figure 7; Booth et al., 2005). In contrast, Kettle Lake shows evidence of moister conditions at c. 4200 cal. yr BP. At other times in zone 2 are short sporadic decadal periods of strongly saline water or meromixis (diatom group 3 and 4), suggesting dramatic fluctuations in the groundwatertable and lake levels. These drought periods predictably show higher diatom community instability during an overall zone of relative assemblage stability (Figure 7).

Around 1406 cal. yr BP, there is an increased abundance of benthic diatoms (group 2). While the reconstructed DI-salinity is similar to Kettle Lake's current salinity (Figure 4), the community assemblage is relatively unstable. A diatom subzone from 1406 to 872 cal. yr BP (zone 2c, Figure 6) is characterized by some of the highest rate-of-change values, lower groundwater flow and much drier conditions (group 2, 3, and 4 diatoms) (Figure 7). The base of this subzone corresponds closely with the base of mineral/pollen zone E3, which these proxies indicate as drier than underlying zone E2 (Grimm et al., 2011). Zone E3 exhibits a tripartite dry-wet-dry sequence. The earliest dry interval dating to 1460-900 cal. yr BP corresponds closely with diatom zone $2 \mathrm{c}$ and is coincident with the 'Medieval Climate Anomaly' (MCA; Bradley et al., 2003). Drought was common during the MCA and has been documented in a number of other western paleoclimatic records (Herweijer et al., 2007; Woodhouse, 2004). Regionally, this shift is coincident with Ceylon Lake to the northwest, which also shows a transition from high lake levels at $2000 \mathrm{cal}$. yr $\mathrm{BP}$ to a low level at $\sim 1500 \mathrm{cal}$. yr BP and a return to high lake levels by 1000 cal. yr BP (Teller and Last, 1990). In Kettle Lake the abrupt increase in salinity at 1406 cal. yr BP is followed by large decadal fluctuations in salinity, returning to fresher conditions. At $\sim 872$ cal. yr BP, another abrupt diatom assemblage shift takes place (zone $2 \mathrm{~d}$, Figure 7 ), where fairly stable, freshwater diatom communities dominate from 872 to 620 cal. yr BP (Figure 3 and 7). Zone 2d corresponds closely with the wet middle section of mineral/pollen zone E3 dated to $~ 900-600$ cal. yr BP, which also indicates wetter conditions (Grimm et al., 2011). Other diatom records from North Dakota show a complex response both temporally and spatially during this period, with evidence of arid and wetter periods (Fritz 
et al., 2000). It is becoming evident that the heterogeneity of lake responses to arid periods is related to the lake's connection to the groundwater table (Almendinger, 1993; Fritz et al., 2000; Laird et al., 2007). Indeed, the strong connectivity of Kettle Lake to the Little Muddy Aquifer would lead to its relative biological stability during climatically instable periods.

Zone 3 (620 cal. yr BP to present). Zone 3 in the diatom record of Kettle Lake represents the transition into the 'Little Ice Age' (LIA) and a rapid transition to a more arid climate and unstable diatom communities until 113 cal. yr BP (zone 3a, Figure 7). Each of the four diatom groups dominates at some point during this period, suggesting variable lake levels and groundwater flow from a more variable climate (Figure 7). Group 2 diatoms, which include both freshwater and subsaline benthic species, are prominent during the early LIA, suggesting that cold spring temperatures and moderately arid climate prevailed (Fritz et al., 1994). Colder temperatures could also favour benthic diatoms, as a long period of lake-ice cover would mean a reduced spring mixing and short planktic growing season. Freshwater conditions (group 1 diatoms) dominate near the end of the LIA ( 350 to 113 cal. yr BP), suggesting a gradual transition to wetter conditions. This pattern of a cool arid early-LIA transitioning into a cool, moist lateLIA ( 350 cal. yr BP) also was apparent to the east in Elk Lake, Minnesota (Bradbury and Dieterich-Rurup, 1993). It should be emphasized that although zone 3 is somewhat drier than the preceding 300 years (Figure 7), the magnitude of this aridity is nowhere near that of the mid Holocene. Other records from North Dakota, including Devils, Moon, Coldwater, and Rice Lakes, all have a much more complex response to the LIA climate (Figure 1; Fritz et al., 1994, 2000).

The modern period (zone 3b, Figure 6; 113 cal. yr BP to present) continued as relatively arid and unstable, with all four lake regimes dominating at some point. Decadal periods of meromixis occurred early in this period following a transition from group 2 to 3 diatoms. This pattern suggests a gradual lowering of lake level in response to reduced groundwater flow. The large 'Dust Bowl' era drought of the 1930s is recorded in an abundance of group 3 and 4 diatoms, however, the corresponding salinity during this time is only slightly above the modern value (Figure 4). Comparing the inferred lake state and salinity of the 'Dust Bowl' with the rest of the record, suggests that droughts more severe than the Dust Bowl, both in duration and aridity, were prevalent throughout the last 8500 years at Kettle Lake. The diatom rate-of-change for the modern period and the end of the LIA also suggests that the recent climate is generally more unstable than any other extended period over the last 8500 years.

\section{Conclusion}

The regional climatic and hydrologic gradients in the NGP are strong and pose a significant challenge to reconstructing a coherent picture of North American climate. We have shown that the use of an independent proxy of groundwater flow provides an effective means to interpret the biological response through time, in a closed-basin lake ecosystem that is intimately tied to the local aquifer. At the millennialscale there is strong evidence for regional climatic re-arrangements, particularly at $\sim 4500$ cal. yr BP. Both the diatom and geochemical record from Kettle Lake, suggest periods of meromixis during the mid Holocene and the last 600 years. At the decadal-centennial scale the diatom record from Kettle Lake shows no clear cyclic trends over the last 8500 years. However, periods of prolonged ( 100 years) and rapid (2030 years) drought have taken place throughout the mid to late Holocene. These droughts appear to have had similar impacts on the Kettle Lake hydrology as the 'Dust Bowl' era droughts, but were longer in duration.

Acknowledgments - We would like to thank George L. Jacobson Jr, James S. Clark, Wayne Lusardi, and Bryan Shuman who successfully retrieved the core. Pietra G. Mueller sieved the sediments for macrofossils and charcoal and prepared specimens for AMS radiocarbon dating. Statistical advice was given by Steve Juggins. This work was funded by National Science Foundation grants to S. C. Fritz (EAR06-02154), E. C. Grimm (ATM-0213246), and J. J. Donovan (ATM-0214108).

\section{References}

Alley RB, Mayewski PA, Sowers T, Stuiver M, Taylor KC and Clark PU (1997) Holocene climatic instability: A prominent, widespread event 8200 yr ago. Geology 26: 483-486.

Almendinger JE (1993) A groundwater model to explain past lake levels at Parkers Prairie, Minnesota, USA. The Holocene 3: 105-115.

Battarbee RW, Jones VJ, Flower RJ, Cameron N, Bennion H, Carvalho L et al. (2001) Diatoms. In: Smol JP, Birks HJB and Last WM (eds) Tracking Environmental Change Using Lake Sediments Vol 3. Dordrecht: Kluwer, 155-202.

Bennett KD (1996) Determination of the number of zones in a biostratigraphical sequence. New Phytology 132: 155-170.

Booth RK, Jackson ST, Forman SL, Kutzbach JE, Bettis EA III, Kreigs J et al. (2005) A severe centennial-scale drought in midcontinental North America 4200 years ago and apparent global linkages. The Holocene 15(3): 321-328.

Bradbury JP (1988) A climatic-limnological model of diatom succession for paleolimnological interpretation of varved sediments at Elk Lake, Minnesota. Journal of Paleolimnology 1: 115-131.

Bradbury JP and Dieterich-Rurup KV (1993) Holocene diatom palaeolimnology of Elk Lake, Minnesota. In: Bradbury JP and Dean WE (eds) Elk Lake, Minnesota: Evidence for Rapid Climate Change in the North-Central United States. Colorado: Geological Society of America Special Paper 276, 215-237.

Bradley RS, Briffa KR, Cole J, Hughes MK and Osborn TJ (2003) The climate of the last millennium. In: Alverson K, Bradley RS and Pedersen TF (eds) Paleoclimate, Global Change and the Future. Berlin: Springer Verlag, 105-141.

Brugam RB (1983) The relationship between fossil diatom assemblages and limnological conditions. Hydrobiologia 98: 223-235.

Buck CE, Christen JA and James GN (1999) BCal: An on-line Bayesian radiocarbon calibration tool. Internet Archaeology 7: available at: http://intarch.ac.uk/journal/issue7/buck_index. $\underline{\mathrm{html}}$

Clark JS, Grimm EC, Donovan JJ, Fritz SC, Engstrom DR and Almendinger JE (2002) Drought cycles and landscape responses to past aridity on prairies of the northern Great Plains, USA. Ecology 83: 595-601. 
Cumming BF, Laird KR, Bennett JR, Smol JP and Saloman AK (2002) Persistent millennial-scale shifts in moisture regimes in western Canada during the past six millennia. Proceedings of the National Academy of Sciences, USA 99: 16 117-16 121.

Cumming BF, Wilson SE, Hall RI and Smol JP (1995) Diatoms from British Columbia (Canada) Lakes and their Relationship to Salinity, Nutrients and other Limnological Variables. Bibliotheca Diatomologica 31, Berlin, Stuttgart: J. Cramer.

Dean WE (1993) Physical properties, mineralogy, and geochemistry of Holocene varved sediments from Elk Lake, Minnesota. In: Bradbury JP and Dean WE (eds) Elk Lake, Minnesota: Evidence for Rapid Climate Change in the North-Central United States. Colorado: Geological Society of America Special Paper 276: 135-157.

Dean WE, Ahlbrandt TS, Anderson RY and Bradbury JP (1996) Regional aridity in North America during the middle Holocene. The Holocene 6: 145-155.

Donovan JJ and Grimm EC (2007) Episodic struvite deposits in a northern Great Plains flyway lake: Indicators of mid-Holocene drought? The Holocene 17: 1155-1169.

Foged N (1981) Diatoms in Alaska. Vaduz: Cramer.

Fritz SC (1990) Twentieth-century salinity and water-level fluctuations in Devils Lake, North Dakota: Test of a diatom-based transfer function. Limnology and Oceanography 35: 1771-1781.

Fritz SC (2008) Deciphering climatic history from lake sediments. Journal of Paleolimnology 39: 5-16.

Fritz SC, Engstrom DR and Haskell BJ (1994) 'Little Ice Age' aridity in the northern American Great Plains: A high-resolution reconstruction of salinity fluctuations from Devils Lake, North Dakota, USA. The Holocene 4: 69-73.

Fritz SC, Ito E, Yu Z, Laird KR and Engstrom DR (2000) Hydrologic variation in the Northern Great Plains during the last two millennia. Quaternary Research 53: 175-184.

Fritz SC, Juggins S and Battarbee RW (1993) Diatom assemblages and ionic characterization of lakes of the northern Great Plains, North America: A tool for reconstructing past salinity and climate fluctuations. Canadian Journal of Fisheries and Aquatic Sciences 50: 1844-1856.

Grimm EC (1987) CONISS, a Fortran 77 program for stratigraphically constrained cluster analysis by the method of incremental sum of squares. Computers and Geosciences 13: 13-35.

Grimm EC (2001) Trends and paleoecological problems in the vegetation and climate history of the northern Great Plains, USA. Biology and Environment: Proceedings of the Royal Irish Academy 101: 47-64.

Grimm EC (2011) High-resolution age model based on AMS radiocarbon dates for Kettle Lake, North Dakota. Radiocarbon 53(1): 39-53.

Grimm EC, Donovan JJ and Brown KJ (2011) A high-resolution mineral, pollen, and charcoal record of climatic variability and landscape response from Kettle Lake in the Northern Great Plains of North America. Quaternary Science Reviews. DOI: 10.1016/j.quascirev.2011.05.015.

Herweijer C, Seager R, Cook ER and Emile-Geay J (2007) North American droughts of the last millennium from a gridded network of tree-ring data. Journal of Climate 20: 1353-1376.

Hürlimann J and Schanz F (1993) The effects of artificial ammonium enhancement on riverine periphytic diatom communities. Aquatic Sciences 55: 40-64.

Interlandi SJ, Kilham SS and Theriot EC (1999) Responses of phytoplankton to varied resource availability in large lakes of the
Greater Yellowstone Ecosystem. Limnology and Oceanography 44: 668-682.

Jacobson GL and Grimm EC (1986) A numerical analysis of Holocene forest and prairie vegetation in central Minnesota. Ecology 67: 958-966.

Juggins S (2003) C2 Software for Ecological and Palaeoecological Data Analysis and Visualisation User Guide Version 1.3. University of Newcastle.

Kilham SS, Theriot EC and Fritz SC (1996) Linking planktonic diatoms and climate change in the large lakes of the Yellowstone ecosystem using resource theory. Limnology and Oceanography 41: 1052-1062.

Krammer K and Lange-Bertalot H (1986) Bacillariophyceae. 1. Teil: Naviculaceae. In: Ettl H, Gärtner G, Gerloff J, Heynig H and Mollenhauer D (eds) Süßwasserflora von Mitteleuropa, Band 2/1. Stuttgart/New York: Gustav Fischer Verlag, 876 pp.

Krammer K and Lange-Bertalot H (1988) Bacillariophyceae. 2. Teil: Bacillariaceae, Epithemiaceae, Surirellaceae. In: Ettl H, Gärtner G, Gerloff J, Heynig H and Mollenhauer D (eds) Süßwasserflora von Mitteleuropa, Band 2/2. Stuttgart/New York: Gustav Fischer Verlag, $596 \mathrm{pp}$.

Krammer K and Lange-Bertalot H (1991a) Bacillariophyceae. 3. Teil: Centrales, Fragilariaceae, Eunotiaceae. In: Ettl H, Gärtner G, Gerloff J, Heynig H and Mollenhauer D (eds) Süßwasserflora von Mitteleuropa, Band 2/3. Stuttgart/Jena: Gustav Fischer Verlag, $576 \mathrm{pp}$.

Krammer K and Lange-Bertalot H (1991b) Bacillariophyceae. 4. Teil: Achnanthaceae Kritische Ergäzungen zu Navicula (Lineolatae) und Gomphonema. In: Ettl H, Gärtner G, Gerloff J, Heynig $\mathrm{H}$ and Mollenhauer D (eds) Süßwasserflora von Mitteleuropa, Band 2/4. Stuttgart/Jean: Gustav Fischer Verlag, 437 pp.

Laird KR and Cumming BF (2008) Reconstruction of Holocene lake level from diatoms, chrysophytes and organic matter in a drainage lake from the Experimental Lakes Area (northwestern Ontario, Canada). Quaternary Research 69: 292-305.

Laird KR, Fritz SC, Cumming BF and Grimm EC (1998) Early-Holocene limnological and climatic variability in the Northern Great Plains. The Holocene 8: 275-285.

Laird KR, Fritz SC, Maasch KA and Cumming BF (1996) Greater drought intensity and frequency before AD 1200 in the Northern Great Plains, USA. Nature 384: 552-554.

Laird KR, Michels A, Stuart CTL, Wilson SE, Last WM and Cumming BF (2007) Examination of diatom-based changes from a climatically sensitive prairie lake (Saskatchewan, Canada) at different temporal perspectives. Quaternary Science Reviews 26: 3328-3343.

Lange-Bertalot H (1978) Diatomeen-Differentialarten anstelle yon Leitformen: Ein geeignetes Kriterium der Gewässerbelastung. Archiv für Hydrobiologie Supplementum 51: 393-427.

Last WM (1990) Paleochemistry and paleohydrology of Ceylon Lake, a salt-dominated playa basin in the northern Great Plains, Canada. Journal of Paleolimnology 4: 219-238.

Last WM (1993) Salt dissolution features in saline lakes of the northern Great Plains, Western Canada. Geomorphology 8: 321-334.

Line JM, ter Braak CJF and Birks HJB (1994) WACALIB version 3.3 - A computer program to reconstruct environmental variables from fossil assemblages by weighted averaging and to derive sample-specific errors of prediction. Journal of Paleolimnology 10: $147-152$.

Lotter AF, Ammann B and Sturm M (1992) Rates of change and chronological problems during the late-glacial period. Climate Dynamics 6: 233-239. 
Paillard D, Labeyrie L and Yiou P (1996) Macintosh program performs time-series analysis. Eos Transactions AGU 77: 379.

Pappas JL and Stoermer EF (1996) Quantitative method for determining a representative algal sample count. Journal of Phycology 32: 693-696.

Patrick R and Reimer CW (1966) The Diatoms of the United States Exclusive of Alaska and Hawaii. Philadelphia: Academy of Natural Sciences of Philadelphia monograph 13, volume 1.

Patrick R and Reimer CW (1975) The Diatoms of the United States Exclusive of Alaska and Hawaii. Philadelphia: Academy of Natural Sciences of Philadelphia monograph 13, volume 2, part 1.

R Core Development Team (2010) R: A Language and Environment for Statistical Computing. Vienna: R Foundation for Statistical Computing, available online: http://www.R-project.org

Reimer PJ, Baillie MGL, Bard E, Bayliss A, Beck JW, Blackwell PG et al. (2009) IntCal09 and Marine09 radiocarbon age calibration curves, 0-50,000 years cal BP. Radiocarbon 51(4): 1111-1150.

Ryves DB, Battarbee RW and Fritz SC (2009) The dilemma of disappearing diatoms: Incorporating diatom dissolution data into palaeoenvironmental modelling and reconstruction. Quaternary Science Reviews 28: 120-136.

Saros JE, Michel TJ, Interlandi SJ and Wolfe AP (2005) Resource requirements of Asterionella formosa and Fragilaria crotonensis in oligotrophic alpine lakes: Implications for recent phytoplankton community reorganizations. Canadian Journal of Fisheries and Aquatic Sciences 61: 1681-1689.

Shapley MD, Ito E and Donovan JJ (2005) Authigenic calcium carbonate flux in groundwater-controlled lakes; implications for lacustrine paleoclimate records. Geochimica et Cosmochimica Acta 69: 2517-2533.

Stoermer EF and Håkansson H (1984) Stephanodiscus parous: Validation of an enigmatic and widely misconstrued taxon. Nova Hedwigia 39: 497-511.
Stone JR and Fritz SC (2006) Multidecadal drought and Holocene climate instability in the Rocky Mountains. Geology 34: 409-412.

Teller JT and Last WM (1990) Paleohydrological indicators in playas and salt lakes, with examples from Canada, Australia, and Africa. Palaeogeography, Palaeoclimatology, Palaeoecology 76: 215-240.

Tilman D and Kilham SS (1976) Phosphate and silicate growth and uptake kinetics of the diatoms Asterionella formosa and Cyclotella meneghiniana in batch and semicontinuous culture. Journal of Phycology 12: 375-383.

Tilman D, Kilham SS and Kilham P (1982) Phytoplankton community ecology: The role of limiting nutrients. Annual Review of Ecology and Systematics 13: 349-372.

Winder M, Reuter JE and Schladow SG (2009) Lake warming favours small-sized planktonic diatom species. Proceedings of the Royal Society B: Biological Sciences 276: 427-435.

Wolin JA and Stone JR (2010) Diatoms as indicators of water-level change in freshwater lakes. In: Smol JP and Stoermer EG (eds) Diatoms: Applications for the Environmental and Earth Sciences, 2nd Edition. Cambridge University Press, $686 \mathrm{pp}$.

Woodbridge J and Roberts N (2010) Linking neo- and palaeolimnology: A case study using crater lake diatoms from central Turkey. Journal of Paleolimnology 44: 855-871.

Woodhouse CA (2004) A paleo perspective on hydroclimatic variability in the western United States. Aquatic Sciences 66: 346-356.

Wright HE Jr (1967) A square-rod piston sampler for lake sediments. Journal of Sedimentary Petrology 37: 975-976.

Yu Z, Ito E, Engstrom DR and Fritz SC (2002) A 2100-year traceelement and stable-isotope record at decadal resolution from Rice Lake in the Northern Great Plains, USA. The Holocene 12: 605-617. 